INOBIS: Jurnal Inovasi Bisnis dan Manajemen Indonesia

Volume 2, Nomor 1, Desember 2018

A.A. Sagung Diah Istri Pramayani; I Gusti Ayu Dewi Adnyani

\title{
Pengaruh Pemberdayaan, Perilaku Inovatif, dan Motivasi Kerja Terhadap Produktifitas Kerja Karyawan Bumbu Bali Restoran Tanjung Benoa Badung, Bali
}

\author{
A.A. Sagung Diah Istri Pramayani \\ I Gusti Ayu Dewi Adnyani \\ Fakultas Ekonomi dan Bisnis Universitas Udayana (Unud), Bali, Indonesia \\ e-mail: g dalam suatu perusahaan dalam mencapai tujuan perusahaan dengan adanya \\ dukungan unigadewi@yahoo.com / telp: +62 81337197622
}

\begin{abstract}
Abstrak
Karyawan merupakan aset pentintuk meningkatkan produktivitasnya.Tujuan dari penelitian ini adalah untuk mengetahui pengaruh pemberdayaan, perilaku inovatif, dan motivasi kerja terhadap produktivitas kerja.. Penelitian ini dilakukan di Bumbu Bali Restoran. Jumlah responden adalah sebanyak 35 orang karyawan dengan metode sampling jenuh. Pada penelitian ini pengumpulan data dilakukan melalui penyebaran kuisioner dengan menggunakan metode pengukuran data skala Likert. Teknik analisis yang digunakan dalam penelitian ini adalah regresi linear berganda. Pemberdayaan memberi kontribusi dalam keberhasilan perusahaan. Memiliki perilaku inovatif juga merupakan hal yang penting untuk mengembangkan inovasi dalam meningkatkan produktivitas. Disamping itu produktivitas dapat ditingkatkan dengan diberikannya dorongan yang mampu memotivasi kerja karyawan. Karyawan hendaknya selalu diberikan kepercayaan, cara cara baru dalam proses bekerja dan senantiasa didukung fasilitas dan perlengkapan kerja untuk meningkatkan produktifitas
\end{abstract}

Kata kunci: pemberdayaan, perilaku inovatif, motivasi kerja dan produktivitas kerja

\section{Pendahuluan}

Produktivitas merupakan hal penting bagi perusahaan dalam menghadapi persaingan yang semakin ketat. Pada organisasi produktivitas dapat ditingkatkan dengan adanya dukungan dari sumber daya manusia (SDM) dalam memotivasi karyawan agar mampu bekerja lebih produktif. Keberhasilan perusahaan dipengaruhi oleh SDM yang bekerja dalam perusahaan tersebut. Semakin produktif karyawan maka semakin tinggi pencapaian perusahaan.

Permasalahan dalam pengelolaan manajeman SDM dapat terjadi di organisasi apa saja, baik itu perusahaan yang bergerak dalam bidang jasa maupun manufaktur. Bumbu Bali Restoran merupakan perusahaan yang bergerak dalam bidang jasa khususnya penyajian makanan. Dalam operasional perusahaan, Bumbu Bali Restoran selalu berusaha untuk memberi pelayanan dan hidangan terbaiknya. Produktivitas karyawan di Bumbu Bali Restoran dapat dilihat pada data capaian penjualan periode 2016 - 2017. 
INOBIS: Jurnal Inovasi Bisnis dan Manajemen Indonesia

Volume 2, Nomor 1, Desember 2018

A.A. Sagung Diah Istri Pramayani; I Gusti Ayu Dewi Adnyani

Tabel 1. Data pencapaan tahun 2016

\begin{tabular}{lcccc}
\hline \multicolumn{1}{c}{ Periode } & $\begin{array}{c}\text { Target per } \\
\text { Bulan }(\mathbf{R p})\end{array}$ & $\begin{array}{c}\text { Capaian } \\
(\mathbf{R p})\end{array}$ & $\begin{array}{c}\text { Persentase } \\
(\mathbf{\%})\end{array}$ & $\begin{array}{c}\text { Pertumbuhan } \\
\text { Pendapatan }\end{array}$ \\
\hline Januari & 65.000 .000 & 58.598 .567 & 90 & \\
Februari & 65.000 .000 & 52.930 .287 & 81 & $-0,0967$ \\
Maret & 65.000 .000 & 50.902 .873 & 78 & $-0,0383$ \\
April & 65.000 .000 & 52.783 .208 & 81 & 0,0369 \\
Mei & 65.000 .000 & 50.312 .097 & 77 & $-0,0468$ \\
Juni & 65.000 .000 & 51.983 .675 & 80 & 0,0332 \\
Juli & 70.000 .000 & 50.750 .934 & 73 & $-0,0237$ \\
Agustus & 70.000 .000 & 56.975 .678 & 81 & 0,1227 \\
September & 70.000 .000 & 46.580 .998 & 67 & $-0,1824$ \\
Oktober & 70.000 .000 & 42.380 .900 & 61 & $-0,0902$ \\
November & 72.000 .000 & 44.672 .345 & 62 & 0,0541 \\
Desember & 72.000 .000 & 48.097 .864 & 67 & 0,0767 \\
& & & & \\
\hline TOTAL & & & $\mathbf{7 5}$ & \\
\hline
\end{tabular}

Tabel 2. Data pencapaan tahun 2017

\begin{tabular}{lcccc}
\hline \multicolumn{1}{c}{ Periode } & $\begin{array}{c}\text { Target per } \\
\text { Bulan (Rp) }\end{array}$ & $\begin{array}{c}\text { Capaian } \\
(\mathbf{R p})\end{array}$ & $\begin{array}{c}\text { Persentase } \\
(\mathbf{\%})\end{array}$ & $\begin{array}{c}\text { Pertumbuha } \\
\mathbf{n} \\
\text { Pendapatan }\end{array}$ \\
\hline Januari & 65.000 .000 & 60.598 .567 & 93 & \\
Februari & 65.000 .000 & 59.897 .685 & 92 & $-0,0116$ \\
Maret & 65.000 .000 & 55.395 .000 & 85 & $-0,0752$ \\
April & 65.000 .000 & 49.783 .208 & 77 & $-0,1013$ \\
Mei & 65.000 .000 & 47.312 .097 & 73 & $-0,0496$ \\
Juni & 65.000 .000 & 48.983 .675 & 75 & 0,0353 \\
Juli & 70.000 .000 & 53.750 .934 & 77 & 0,0973 \\
Agustus & 70.000 .000 & 59.975 .678 & 86 & 0,1158 \\
September & 70.000 .000 & 49.580 .998 & 71 & $-0,1733$ \\
Oktober & 70.000 .000 & 46.380 .900 & 66 & $-0,0645$ \\
November & 70.000 .000 & 51.450 .985 & 74 & 0,1093 \\
Desember & 70.000 .000 & 52.389 .750 & 75 & 0,0182 \\
& & & & \\
\hline \multicolumn{1}{c}{ TOTAL } & & & $\mathbf{7 9}$ &
\end{tabular}

Berdasarkan tabel 1 dan 2 pencapaian tahum 2016 hingga 2017 diketahui bahwa pada bulan Januari 2016 capaian perusahaan mencapai 90\% namun pada bulan bulan berikutnya mengalami penurunan. Berdasarkan tabel capaian tahun 2017 bulan Januari capaian perusahaan mencapai 93\% dan bulan Februari mencapai 92\%, namun pada bulan Maret hingga Desember pencapaian perusahaan mengalami kenaikan dan penurunan. Perusahaan harus memperhatikan dan mempertimbangkan faktor-faktor yang dapat mencapai keberhasilan perusahaan seperti produktivitas karyawan.

Kawara (2014) menegaskan bahwa salah satu pendekatan umum untuk meningkatkan produktivitas karyawan adalah imbalan dengan jumlah dan kualitas kinerja melalui berbagai 
INOBIS: Jurnal Inovasi Bisnis dan Manajemen Indonesia

Volume 2, Nomor 1, Desember 2018

\section{A.A. Sagung Diah Istri Pramayani; I Gusti Ayu Dewi Adnyani}

jenis insentif. Wicaksono (2011) juga menyatakan bahwa produktivitas adalah kemampuan yang dimiliki oleh karyawan untuk melakukan pekerjaan dalam berproduksi dibandingkan dengan karyawan menggunakan input, produktivitas karyawan juga dikatakan tinggi apabila mampu menyelesaikan pekerjaan baik barang ataupun jasa dengan waktu yang tepat dan sesuai dengan yang diharapkan.

Tabel 3. Jumlah karyawan

\begin{tabular}{l|c}
\hline Jabatan & Jumlah (Orang) \\
\hline Manager & 1 \\
\hline Asisten Manager & 1 \\
\hline Captain & 1 \\
\hline Head & 1 \\
\hline Waiter/Waitress & 1 \\
\hline Executive Chef & 1 \\
\hline Souce Chef & 1 \\
\hline Chef de Parte & 9 \\
\hline Cook & 9 \\
\hline Cook Helper & 35 \\
\hline TOTAL &
\end{tabular}

Sumber : Bumbu Bali Restoran, 2017

Berdasarkan tabel 3 dapat diketahui bahwa jumlah karyawan di Bumbu Bali Restoran tahun 2017 adalah sebanyak 35 orang. Disamping indikasi rendahnya produktivitas, juga terdapat permasalahan dalam hal pemberdayaan, motivasi dan perilaku inovatif karyawan. Didukung hasil wawancara terhadap 5 orang karyawan, 3 diantaranya merasa kurangnya kepercayaan dari atasan untuk memberikan tanggung jawab kepada karyawan. Sehingga karyawan merasa kurang diberdayakan dan produktivitasnya cenderung kurang.

Pemanfaatan SDM yang efektif dan efisien sangat penting untuk meningkatkan efektivitas dan efisiensi secara keseluruhan.Produktivitas karyawan adalah salah satu perhatian utama untuk manajemen dalam organisasi apapun. Oleh karena itu, penelitian ini bertujuan untuk mengetahui pengaruh pemberdayaan, perilaku inovatif dan motivasi kerja terhadap produktivitas karyawan di Bumbu Bali Restoran khususnya membahas perusahaan jasa. Berdasarkn rumusan masalah diatas, penelitian ini diharapkan memberikan manfaat yaitu penelitian ini diharapkan dapat menambah bukti empiris tentang studi yang membahas pengaruh variabel pemberdayaan, perilaku inovatif, dan motivasi kerja.

Pemberdayaan diakui memberikan kontribusi bagi keberhasilan organisasi di perusahaan.Terdapat banyak penulis yang meneliti hubungan pemberdayaan terhadap produktivitas.Chang, Liu (2007) menyatakan bahwa pemberdaayaan merupakan faktor penting dalam meningkatkan produktivitas. Karacoc (2009) menyebutkan dengan mengadopsi strategi pemberdayaan, diyakini bahwa karyawan akan merasakan diri mereka layak, dan pada akhirnya dapat meningkatkan produktivitas dan kualitas kerja mereka. Pemberdayaan karyawan telah secara luas diakui sebagai kontributor kunci keberhasilan organisasi, dan banyak penulis mengamati hubungan langsung antara tingkat pemberdayaan karyawan dan produktivitas (Hanasya, 2016).Menurut Alvin et al. (2014) pemberdayaan memberikan pengaruh yang kuat terhadap produktivitas. Berdasarkan pemikiran diatas, hipotesis yang dapat diajukan dalam penelitian ini adalah:

H1 : Pemberdayaan berpengaruh positif terhadap produktivitas 
INOBIS: Jurnal Inovasi Bisnis dan Manajemen Indonesia

Volume 2, Nomor 1, Desember 2018

\section{A.A. Sagung Diah Istri Pramayani; I Gusti Ayu Dewi Adnyani}

Perilaku inovatif memberikan kontribusi besar dalam persaingan perusahaan, karena perilku inovatif dari karyawan mampu memberikan ide terbaru. Chang, Liu (2007) menyatakan bahwa perilaku inovatif merupakan hal yang memiliki kontribusi besar dalam meningkatkan produktivitas. Menurut Kusumawati (2010) bahwa penerapan yang berhasil dari gagasan kreatif yang dimiliki perusahaan mampu menerapkan perilaku yang inovatif bagi karyawan yang dapat meningkatkan produktivitas dalam perusahaan. Putri dan Budiastuti (2012) juga menyatakan bahwa perilaku inovatif memiliki pengaruh positif terhadap produktivitas kerja, perilaku inovatif dapat ditingkatkan dengan mendorong kreativitas karyawan dan perilaku inovatif karyawan. Berdasarkan pemikiran diatas, hipotesis yang dapat diajukan dalam penelitian ini adalah:

H2 : Perilaku Inovatif berpengaruh positif terhadap produktivitas

Motivasi kerja memberikan pengaruh terhadap produktivitas karyawan. Ismajli et.al (2015) menyatakan motivasi berpengaruh positif dan signifikan yang didukung dengan perolehan hasil kerja, gaji, kemajuan profesional dan kesempatan untuk promosi tampaknya merupakan faktor motivasi yang paling penting. Omollo (2015) juga menilai bahwa motivasi berpengaruh positif terhadap produktivitas karyawan jika imbalan yang diterima sesuai dengan apa yang menjadi beban pekerjaan karyawan itu. Chukwuma dan Okafor (2014) juga menjelaskan bahwa produktivitas karyawan yang tinggi dipengaruhi melalui motivasi kerja yang tinggi dengan sejumlah imbalan seperti intensif dan mengupayakan karyawan untuk melakukan upaya terbaik melalui antusiasme dan efektivitas untuk mencapai dantujuan organisasi.

H3 : Motivasi berpengaruh positif terhadap produktivitas

Berdasarkan hubungan antar variabel tersebut, maka dapat disusun kerangka konsep penelitian seperti pada Gambar 1.

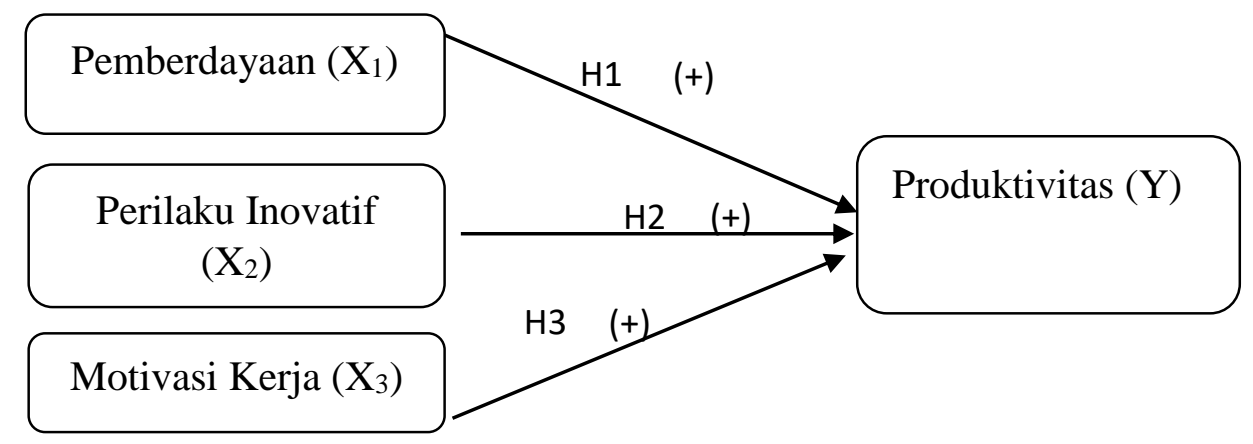

\section{Gambar 1. Model Kerangka Konseptual}

\section{Metode Penelitian}

Desain penelitian asosiatif menjelaskan pengaruh variabel bebas yaitu pemberdayaan $\left(\mathrm{X}_{1}\right)$, perilaku inovatif $\left(\mathrm{X}_{2}\right)$, motivasi kerja $\left(\mathrm{X}_{3}\right)$, terhadap produktivitas $(\mathrm{Y})$.Penelitian ini dilakukan di Bumbu Bali Restoran yang berlokasi di Jalan Pratama - Tanjung Benoa, Nusa Dua.Data kuantitatif berupa data jumlah karyawan serta skor jawaban responden dan data kualitatif berupa hasil wawancara mengenai gambaran umum perusahaan Bumbu Bali Restoran 
INOBIS: Jurnal Inovasi Bisnis dan Manajemen Indonesia

Volume 2, Nomor 1, Desember 2018

A.A. Sagung Diah Istri Pramayani; I Gusti Ayu Dewi Adnyani

Sumber primer diperoleh secara langsung dari karyawan Bumbu Bali Restoran, sedangkan sumber sekunder berupa: jumlah karyawan, laporan pencapaian target perusahaan, struktur organisasi, dan brosur Bumbu Bali Restoran serta pengumpulan data melalui wawancara dan penyebaran kuisioner. Populasi menjadi responden penelitian ini sebanyak 35 orang karyawan dengan Teknik sampel jenuh.

Data diukur dengan skala likert kepada karyawan Bumbu Bali Restoran melalui pernyataan dari indikator masing-masing variabel lalu diukur dengan rentang nilai 1 sampai 5. Instrument penelitian yang digunakan telah diuji melalui uji validitas dan uji reliabilitas

Tabel 4

Hasil Uji Validitas

\begin{tabular}{|c|c|c|c|}
\hline Variabel & Indikator & Koefisien Korelasi & Keterangan \\
\hline Pemberdayaan & $\mathrm{X}_{1.1}$ & 0,888 & Valid \\
\hline \multirow[t]{5}{*}{$\left(\mathrm{X}_{1}\right)$} & $\mathrm{X}_{1.2}$ & 0,955 & Valid \\
\hline & $\mathrm{X}_{1.3}$ & 0,943 & Valid \\
\hline & $\mathrm{X}_{1.4}$ & 0,878 & Valid \\
\hline & $\mathrm{X}_{1.5}$ & 0,871 & Valid \\
\hline & $X_{1.6}$ & 0,931 & Valid \\
\hline \multirow{11}{*}{$\begin{array}{l}\text { Perilaku Inovatif } \\
\qquad\left(\mathrm{X}_{2}\right)\end{array}$} & $\mathrm{X}_{2.1}$ & 0,866 & Valid \\
\hline & $\mathrm{X}_{2.2}$ & 0,888 & Valid \\
\hline & $\mathrm{X}_{2.3}$ & 0,931 & Valid \\
\hline & $\mathrm{X}_{2.4}$ & 0,840 & Valid \\
\hline & $\mathrm{X}_{2.5}$ & 0,890 & Valid \\
\hline & $\mathrm{X}_{2.6}$ & 0,933 & Valid \\
\hline & $\mathrm{X}_{2.7}$ & 0,876 & Valid \\
\hline & $\mathrm{X}_{2.8}$ & 0,868 & Valid \\
\hline & $\mathrm{X}_{2.9}$ & 0,910 & Valid \\
\hline & $\mathrm{X}_{2.10}$ & 0,900 & Valid \\
\hline & $\mathrm{X}_{2.11}$ & 0,899 & Valid \\
\hline \multirow{4}{*}{$\begin{array}{l}\text { Motivasi Kerja } \\
\qquad\left(\mathrm{X}_{3}\right)\end{array}$} & $\mathrm{X}_{3.1}$ & 0,882 & Valid \\
\hline & $\mathrm{X}_{3.2}$ & 0,949 & Valid \\
\hline & $\mathrm{X}_{3.3}$ & 0,899 & Valid \\
\hline & $\mathrm{X}_{3.4}$ & 0,896 & Valid \\
\hline Produktivitas & $\mathrm{Y}_{1.1}$ & 0,929 & Valid \\
\hline \multirow[t]{5}{*}{ Kerja (Y) } & $\mathrm{Y}_{1.2}$ & 0,884 & Valid \\
\hline & $\mathrm{Y}_{1.3}$ & 0,946 & Valid \\
\hline & $\mathrm{Y}_{1.4}$ & 0,906 & Valid \\
\hline & $\mathrm{Y}_{1.5}$ & 0,883 & Valid \\
\hline & $\mathrm{Y}_{1.6}$ & 0,894 & Valid \\
\hline
\end{tabular}

Hasil uji validitas pada Tabel 4 menunjukan bahwa seluruh variabel memiliki nilai koefisien korelasi lebih besar dari 0,3 ( $\mathrm{r}>0,3$ ). Hal ini menyatakan bahwa seluruh butir pernyataan dalam instrumen penelitian tersebut valid. 
INOBIS: Jurnal Inovasi Bisnis dan Manajemen Indonesia Volume 2, Nomor 1, Desember 2018

A.A. Sagung Diah Istri Pramayani; I Gusti Ayu Dewi Adnyani

Tabel 5

Hasil Uji Reabilitas

\begin{tabular}{|c|l|c|c|}
\hline No. & \multicolumn{1}{|c|}{ Variabel } & Cronbach's Alpha & Keterangan \\
\hline 1. & Pemberdayaan $\left(\mathrm{X}_{1}\right)$ & 0,959 & Reliabel \\
\hline 2. & Perilaku Inovatif $\left(\mathrm{X}_{2}\right)$ & 0,974 & Reliabel \\
\hline 3. & Motivasi Kerja $\left(\mathrm{X}_{3}\right)$ & 0,928 & Reliabel \\
\hline 4. & Produktivitas Kerja $(\mathrm{Y})$ & 0,956 & Reliabel \\
\hline
\end{tabular}

Hasil uji reliabilitas pada Tabel 5 menunjukan bahwa seluruh instrumen penelitian memiliki koefisien Cronbach's Alpha lebih besar dari 0,6. Hal ini menyatakan bahwa seluruh instrumen reliabel sehingga dapat digunakan untuk melakukan penelitian. Kuisioner variabel pemberdayaan berisi 6 butir pernyataan dengan nilai Cronbach's Alpha sebesar 0,959 (Khan, 2007). Kuisioner variabel perilaku inovatif berisi 11 butir pernyataan dengan nilai Croncbach's Alpha sebesar 0,974 (Jansen,2000). Variabel motivasi kerja berisi 4 butir pernyataan dengan nilai Cronbach's Alpha sebesar 0,928 (Nurfitri, Lestari 2009) dan variabel produktivitas kerja berisi 6 butir pernyataan dengan nilai Cronbach's Alpha sebesar 0,956 (Sutrisno, 2007)

Data penelitian kemudian diolah dengan menganalisis secara deskriptif serta inferensial.Analisis deskriptif dapat menghasilkan informasi distribusi skor rata-rata respon individu dan juga dilakukan uji hipotesis penelitian melalui metode regresi linier. Teknik analisis regresi linear berganda didukung program SPSS (Statistical Package for Service Solution) versi 18.0. Model regresi linear berganda dirumuskan sebagai berikut:

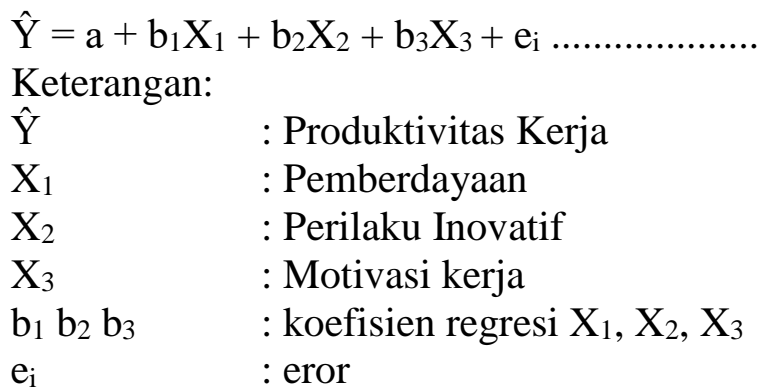

Hasil keluaran dari model regresi yang diciptakan dilengkapi dengan uji asumsi klasik melalui uji normalitas, uji multikolinearitas, dan uji heteroskedostisitas. Untuk uji ketepatan model dilakukan dengan uji statistik $\mathrm{F}$ dan uji koefisien determinasi $\left(\mathrm{R}^{2}\right)$.Untuk pengujian hipotesis dilakukan dengan uji parsial (Uji t).

\section{Hasil dan Pembahasan}

\subsection{Karakteristik Responden}

Karakteristik responden didominasi berjenis kelamin laki-laki sejumlah 22 orang atau 62,86 persen. Responden sebagian besar berusia kisaran 16-25 dengan persentase 34,29 sebanyak 12 orang hingga 26-35 tahun dengan persentase sebesar 34,29 yaitu sebanyak 12 orang. Karyawan yang bekerja di Bumbu Bali Restoran didominasi memiliki masa kerja diatas 3 tahun sebanyak 24 orang dengan persentase 68,58 persen yang dapat dilihat pada Tabel 6. 
INOBIS: Jurnal Inovasi Bisnis dan Manajemen Indonesia

Volume 2, Nomor 1, Desember 2018

A.A. Sagung Diah Istri Pramayani; I Gusti Ayu Dewi Adnyani

Tabel 6

Karakteristik Responden

\begin{tabular}{|c|c|c|c|c|}
\hline No & Karakteristik & Klasifikasi & $\begin{array}{l}\text { Jumlah } \\
\text { (orang) }\end{array}$ & Presentase $(\%)$ \\
\hline \multirow{3}{*}{1.} & \multirow{2}{*}{ Jenis Kelamin } & Laki-laki & 22 & 62,86 \\
\hline & & Perempuan & 13 & 37,14 \\
\hline & \multicolumn{2}{|c|}{ Jumlah } & 35 & 100 \\
\hline \multirow{4}{*}{2.} & \multirow{3}{*}{ Usia } & $16-25$ & 12 & 34,29 \\
\hline & & $26-35$ & 12 & 34,29 \\
\hline & & $36-45$ & 11 & 31,42 \\
\hline & \multicolumn{2}{|c|}{ Jumlah } & 35 & 100 \\
\hline \multirow{7}{*}{3.} & \multirow{6}{*}{ Pendidikan } & $\mathrm{SD}$ & 1 & 2,86 \\
\hline & & SMP & 2 & 5,71 \\
\hline & & SMA/SMK & 24 & 68,58 \\
\hline & & Diploma 1 (D1) & 4 & 11,42 \\
\hline & & Diploma 2 (D2) & 3 & 8,57 \\
\hline & & Sarjana (S1) & 1 & 2,86 \\
\hline & \multirow{5}{*}{ Masa Kerja } & lah & 35 & 100 \\
\hline \multirow{4}{*}{4.} & & $<1$ tahun & 2 & 5,71 \\
\hline & & 1-2 tahun & 9 & 25,71 \\
\hline & & $>3$ tahun & 24 & 68,58 \\
\hline & & Jumlah & 35 & 100 \\
\hline
\end{tabular}

Sumber: Hasil Pengolahan Data Penelitian

Setelah dilakukan tabulasi hasil jawaban responden dilaporkan hasil penelitian sehingga diinterpretasikan dan selanjutnya nilai rata-rata skor setiap variabel diukur melalui rata-rata skor yang dikategorikan menjadi lolima bagian (Wirawan, 2014) yaitu: 1,00-1,80 (sangat rendah/sangat buruk) 1,81 - 2,61 (rendah/buruk) 2,61 - 3,40 (cukup tinggi/cukup baik) 3,41 - 4,20 (tinggi/baik) 4,21 - 5,00 (sangat tinggi/sangat baik)

\subsection{Rangkuman Hasil Deskripsi Variabel}

Tabel 7

Deskripsi Jawaban Responden Variabel Pemberdayaan

\begin{tabular}{llllllllll} 
No. & \multicolumn{3}{c}{ Indikator } & \multicolumn{3}{c}{ Jawaban Responden } & $\begin{array}{c}\text { Rata-rata } \\
\text { Skor }\end{array}$ & Kategori \\
& & STS & TS & N & S & SS & & \\
1. & Keinginan & 0 & 8 & 2 & 12 & 13 & 3,85 & Baik \\
2. & Kepercayaan & 0 & 8 & 5 & 6 & 16 & 3,85 & Baik \\
3. & Kepercayaan diri & 0 & 7 & 3 & 6 & 19 & 4,05 & Baik \\
4. & Kredibilitas & 0 & 8 & 5 & 7 & 15 & 3,82 & Baik \\
5. & Akuntabilitas & 0 & 6 & 6 & 5 & 18 & 4,00 & Baik \\
6. & Komunikasi & 0 & 7 & 6 & 6 & 16 & 3,88 & Baik \\
\multicolumn{6}{c}{ Total rata-rata pemberdayaan } & & & 3,90 & Baik
\end{tabular}

Sumber: Hasil Pengolahan data penelitian 
INOBIS: Jurnal Inovasi Bisnis dan Manajemen Indonesia

Volume 2, Nomor 1, Desember 2018

\section{A.A. Sagung Diah Istri Pramayani; I Gusti Ayu Dewi Adnyani}

Penjelasan variabel pemberdayaan pada Tabel 7 yang menunjukkan nilai rata-rata skor melalui 6 butir pernyataan adalah 3,90. Nilai tersebut berarti pemberdayaan di Bumbu Bali Restoran tergolong baik. Kondisi pemberdayaan ini terlihat dari indicator akuntabilitas sebesar 4,00. Skor tersebut ada pada rentang 3,41-4,20 dalam kategori baik. Hal ini berarti secara keseluruhan responden merasa diberi kepercayaan dalam pembuatan keputusan.

\begin{tabular}{|c|c|c|c|c|c|c|c|}
\hline \multicolumn{8}{|c|}{ Tabel 8} \\
\hline \multirow[t]{2}{*}{ No. } & \multirow[t]{2}{*}{ Indikator } & \multicolumn{4}{|c|}{ Jawaban Responden } & \multirow{2}{*}{$\begin{array}{c}\text { Rata-rata } \\
\text { Skor }\end{array}$} & \multirow[t]{2}{*}{ Kategori } \\
\hline & & STS TS & $\mathrm{N}$ & $\mathrm{S}$ & SS & & \\
\hline 1. & Melihat peluang & $0 \quad 7$ & 2 & 6 & 20 & 4,07 & Baik \\
\hline 2. & Melihat peluang & 0 & 9 & 5 & 16 & & Baik \\
\hline 3. & Mengeluarkan Ide & 0 & 3 & 11 & 15 & 3,92 & Baik \\
\hline 4. & Mengeluarkan Ide & 0 & 10 & 10 & 12 & & Baik \\
\hline 5. & Memperjuangkan & 0 & 9 & 7 & 15 & 4,02 & Baik \\
\hline 6. & Memperjuangkan & 0 & 4 & 12 & 14 & 3,90 & Baik \\
\hline 7. & Memperjuangkan & 0 & 5 & 7 & 17 & & Baik \\
\hline 8. & Memperjuangkan & 0 & 10 & 5 & 16 & & Baik \\
\hline 9. & Aplikasi & 0 & 6 & 10 & 13 & 3,97 & Baik \\
\hline 10. & Aplikasi & 0 & 5 & 3 & 20 & & Baik \\
\hline 11. & Aplikasi & 06 & 5 & 6 & 18 & & Baik \\
\hline & Total rata- & a sama tin & & & & 3.97 & Baik \\
\hline
\end{tabular}

Sumber: Hasil Pengolahan data penelitian

Penjelasan variabel perilaku inovatif pada tabel 8 yang menunjukkan nilai rata-rata skor melalui 11 butir pernyataan adalah 3,97. Nilai tersebut berarti perilaku inovatif di Bumbu Bali Restoran tergolong baik. Kondisi perilaku inovatif ini terlihat dari inikator melihat peluang sebesar 4,11. Skor tersebut terletak pada rentang 3,41-4,20 dalam kategori baik. Hal in berate secara keseluruhan responden setuju bahwa setiap anggota memiliki keinginan untuk memenuhi kebutuhan konsumen. Skor yang paling rendah adalah 3,85 yaitu pernyataan kurangnya cara baru dalam proses pelayanan.

Tabel 9

NO.

Deskripsi Jawaban Responden Variabel Motivasi Kerja INDIKATOR JAWABAN RATA- KATEGOR RESPONDEN RATA I

1. Rasa aman STS TS N $\quad$ S SS SKOR

2. Penghargaan

$\begin{array}{lllllll}0 & 6 & 4 & 8 & 17 & 3,94 & \text { Baik }\end{array}$

3. Kelengkapan

$\begin{array}{llllll}0 & 6 & 6 & 7 & 16 & 4,00\end{array}$

$\begin{array}{llllll}0 & 5 & 6 & 8 & 16 & 3,88\end{array}$

4. Kesempatan Berkarir

$\begin{array}{lllll}0 & 6 & 7 & 7 & 15\end{array}$

TOTAL RATA-RATA PELATIHAN

Sumber: Hasil pengolahan data penelitian

4,20 Baik

4,00 Baik

Penjelasan variabel motivasi kerja pada table 9 yang menunjukan nilai rata-rata skor melalui 4 butir pernyataan adalah 4,00. Nilai tersebut bearti motivasi kerja di Bumbu Bali Restoran tergolong baik. Kondisi pelatihan ini terlihat dari indikator kesempatan berkarier sebesar 4,20. Skor tersebut berada pada rentang 3,41-4,20 dalam kategori baik. Hal ini berarti 
INOBIS: Jurnal Inovasi Bisnis dan Manajemen Indonesia

Volume 2, Nomor 1, Desember 2018

A.A. Sagung Diah Istri Pramayani; I Gusti Ayu Dewi Adnyani

secara keseluruhan responden setuju bahwa perusahaan memberikan kesempatan berkarir. Skor tersendah adalah 3,88 pada indikator kelengkapan.

Tabel 10

Deskripsi Jawaban Responden Variabel Produktivitas Kerja

\begin{tabular}{|c|c|c|c|c|c|c|c|c|}
\hline \multirow[t]{2}{*}{ No. } & \multirow[t]{2}{*}{ Indikator } & \multicolumn{5}{|c|}{$\begin{array}{c}\text { Jawaban } \\
\text { Responden }\end{array}$} & \multirow{2}{*}{$\begin{array}{c}\text { Rata- } \\
\text { rata } \\
\text { Skor }\end{array}$} & \multirow[t]{2}{*}{ Kategori } \\
\hline & & STS & TS & $\mathrm{N}$ & $\mathrm{S}$ & SS & & \\
\hline 1. & Kemampuan & 0 & 6 & 3 & 4 & 22 & 4,20 & Tinggi \\
\hline 2. & $\begin{array}{l}\text { Meningkatkan hasil yang } \\
\text { dicapai }\end{array}$ & 0 & 5 & 9 & 7 & 14 & 3,85 & Tinggi \\
\hline 3. & Semangat kerja & 0 & 5 & 5 & $\begin{array}{l}1 \\
0\end{array}$ & 15 & 4,00 & Tinggi \\
\hline 4. & Pengembangan diri & 0 & 6 & 7 & 5 & 17 & 3,94 & Tinggi \\
\hline 5. & Mutu & 0 & 7 & 5 & 5 & 18 & 3,97 & Tinggi \\
\hline 6. & Efisiensi & 0 & 7 & 5 & 7 & 16 & 3,91 & Tinggi \\
\hline & Total rata-rata produktiv & itas $k$ & arya & wan & & & 3,97 & Tinggi \\
\hline
\end{tabular}

Sumber: Hasil Pengolahan data penelitian

Penjelasan variabel produktivitas kerja pada Tabel 10 yang menunjukkan nilai rata-rata skor melalui 6 butir pernyataan adalah 3,97. Nilai tersebut berarti produktivitas kerja karyawan di Bumbu Bali Restoran tergolong tinggi. Kondisi produktivitas kerja karyawan dapat dilihat dari indikator kemampuan sebesar 4,20. Skor tersebut terletak pada rentang 3,41-4,20 dalam kategori tinggi. Hal ini berarti secara keseluruhan responden setuju bahwa mereka memiliki kemampuan untuk mengerjaka pekerjaan sesuai dengan tugas. Skor yang paling rendah adalah 3,85 yaitu pada indikator meningkatkan hasil yang dicapai. Hal ini berarti responden tidak selalu meningkatkan hasil yang dicapai dari sebelumnya.

\subsection{Hasil Analisis Linear Berganda}

Tabel 11

Rangkuman Analisis Regresi Linear Berganda

\begin{tabular}{|c|c|c|c|c|c|}
\hline \multirow[t]{2}{*}{ Model } & \multicolumn{2}{|c|}{$\begin{array}{c}\text { Unstandardized } \\
\text { Coefficients }\end{array}$} & \multirow{2}{*}{$\begin{array}{c}\text { Standardized } \\
\text { Coefficients } \\
\text { Beta }\end{array}$} & \multirow[t]{2}{*}{$\mathbf{t}$} & \multirow[t]{2}{*}{ Sig. } \\
\hline & B & $\begin{array}{c}\text { Std. } \\
\text { Error }\end{array}$ & & & \\
\hline 1 (Constant) & $-3,847$ & 2,168 & & $-1,787$ & 0,084 \\
\hline Pemberdayaan & 0,364 & 0,095 & 0,366 & 3,819 & 0,001 \\
\hline Perilaku Inovatif & 0,235 & 0,052 & 0,423 & 4,491 & 0,000 \\
\hline Motivasi Kerja & 0,674 & 0,142 & 0,449 & 4,729 & 0,000 \\
\hline $\mathrm{R}$ & & & & & 0,863 \\
\hline R Square & & & & & 0,745 \\
\hline F Statistik & & & & & 30,200 \\
\hline Signifikansi & & & & & 0,000 \\
\hline
\end{tabular}


INOBIS: Jurnal Inovasi Bisnis dan Manajemen Indonesia

Volume 2, Nomor 1, Desember 2018

A.A. Sagung Diah Istri Pramayani; I Gusti Ayu Dewi Adnyani

\subsection{Hasil Uji Asumsi Klasik}

Tabel 12

Hasil Uji Normalitas

\begin{tabular}{l|l}
\multicolumn{1}{c}{} & Residu \\
& Unstand. \\
\hline $\mathrm{N}$ & 35 \\
Kolmogorov-Smirnov Z & 0,148 \\
Asymp.Sig.(2-tailed) & 0,051
\end{tabular}

Sumber: Hasil pengolahan data penelitian

Tabel 12 melaporkan Nilai Kolmogorov-Smirnovsebesar 0,148 dan nilai Asymp.Sigsebesar0,051 lebih besar 0,05ini berarti residual dari persamaan regresi dalam penelitian ini terdistribusi secara normal. Nilai Kolmogorov-Smirnovmerupakan koefisien yang digunakan untuk mengukur kenormalan distribusi data.

\begin{tabular}{ccc}
\multicolumn{2}{c}{ Tabel 13 } & \\
Hasil Uji Multikolinearitas & \\
Tolerance & VIF \\
\hline Pemberdayaan & 0,896 & 1,117 \\
Perilaku Inovatif & 0,928 & 1,078 \\
Motivasi Kerja & 0,913 & 1,095
\end{tabular}

Sumber: Hasil pengolahan data penelitian

Tabel 13 melaporkan keseluruhan variabel pemberdayaan, perilaku inovatif dan motivasi kerja menunjukan nilai tolerance $>0,1$ dan nilai VIF $<10$ artinya hasil regresi bebas multikolinearitas.

\begin{tabular}{|c|c|c|}
\hline \multicolumn{3}{|c|}{$\begin{array}{c}\text { Tabel } 14 \\
\text { Hasil Uji Heteroskedastisitas }\end{array}$} \\
\hline Variabel & thitung & Sig. \\
\hline Pemberdayaan & $-0,253$ & 0,802 \\
\hline Perilaku Inovatif & $-0,378$ & 0,702 \\
\hline Motivasi Kerja & $-1,202$ & 0,239 \\
\hline
\end{tabular}

Sumber: Hasil pengolahan data penelitian

Tabel 13 melaporkan keseluruhan nilai Sig. variabel pemberdayaan, perilaku inovatif dan motivasi kerja lebih besar 0,05. Hal ini berarti memenuhi syarat homoskedastisitas dan bebas gejala heteroskedastisitas.

Uji ketepatan model dirangkum pada nilai signifikansi F Statistik sebesar 0,000 lebih kecil dari nilai $\alpha=0,05$ maka model regresi linear berganda tepat digunakan dalam menguji pengaruh variabel bebas yaitu pemberdayaan, perilaku inovatif dan motivasi kerja terhadap variabel terikat yaitu produktivitas kerja. Hasil Uji F yang signifikan selanjutnya merupakan syarat untuk dapat dapat menginterpretasikan seberapa konstribusi variabel bebas terhadap variabel terikat. 
INOBIS: Jurnal Inovasi Bisnis dan Manajemen Indonesia

Volume 2, Nomor 1, Desember 2018

\section{A.A. Sagung Diah Istri Pramayani; I Gusti Ayu Dewi Adnyani}

Penjelasan nilai $\mathrm{R}^{2}$ dapat digunakan untuk mengukur seberapa besar presentase hubungan produktivitas karyawan dapat ditingkatkan dengan variabel pemberdayaan, kerja sama tim dan pelatihan. Nilai koefisien $\mathrm{R}^{2}$ sebesar 0,676 memiliki arti bahwa pemberdayaan, kerja sama tim dan pelatihan dapat menjelaskan variabel produktivitas karyawan sebesar 74,5 persen dan 25,5 persen sisanya dipengaruhi oleh faktor lain diluar model penelitian ini.

Hasil rangkuman analisis regresi linear berganda Tabel 9 digunakan untuk pengujian hipotesis yang menyatakan bahwa persamaan yang diciptakan yaitu:

$$
\hat{Y}=3,874+0,364 X_{1}+0,235 X_{2}+0,674 X_{3}+e_{i}
$$

Nilai pada kolom regresi B menyatakan bahwa pemberdayaan sebesar 0,364 perilaku inovatif sebesar 0,235 dan motivasi kerja sebesar 0,674 nilai tersebut mengarah pada pengaruh positif. Kemudian keseluruhan variabel tersebut menunjukkan nilai signifikansi lebih kecil dari pengujian $\alpha=0,05$. Hal ini berarti variabel pemberdayaan, perilaku inovatif dan motivasi kerja secara parsial berpengaruh positif dan signifikan terhadap variabel terikat yaitu produktivitas karyawan.

\subsection{Pembahasan Hasil Penelitian}

\subsubsection{Pengaruh Pemberdayaan Terhadap Produktivitas Kerja}

Pemberdayaan memperoleh rata-rata skor 3,90. Dapat dinyatakan karyawan di Bumbu Bali Restoran memperoleh pemberdayaan yang tergolong dalam kategori baik.Hal ini mendukung hipotesis pertama (H1) yaitu pemberdayaan berpengaruh positif terhadap produktivitas karyawan di Bumbu Bali Restoran.Alvin et al. (2014) menyatakan bahwa pemberdayaan memberikan dampak yang positif dan pengaruh yang kuat terhadap produktivitas.Chang, Liu (2007) yang menyatakan bahwa pemberdayaan mengarah ke hasil positif organisasi, seperti tanggung jawab dan motivasi dalam pekerjaan rutin ditingkat karyawan, meningkatkan kepuasan kerja, kualitas layanan yang lebih baik, loyalitas karyawan yang lebih tinggi, dan memaksimalkan produktivitas.Chehrazi dan Shafizadeh (2016) menyatakan terdapat hubungan erat antara pemberdayaan karyawan dengan kepuasan kerja, sehingga meningkatkan produktivitas.Karacoc (2009) menyebutkan bahwa dengan diadopsinya strategi pemberdayaan, diyakini bahwa karyawan merasakan diri mereka layak dan dapat meningkatkan produktivitas dan kualitas kerja mereka.

\subsubsection{Pengaruh Perilaku Inovatif Terhadap Produktivitas Kerja}

Perilaku inovatif memperoleh rata-rata skor sebesar 3,97. Hal ini menunjukkan bahwa responden di Bumbu Bali Restoran melakukan perilaku inovatif yang tergolong dalam kategori baik.Hasil penelitian ini mendukung hipotesis kedua $(\mathrm{H} 2)$ yaitu perilaku inovatif berpengaruh positif terhadap produktivitas kerja di Bumbu Bali Restoran.Chang, Liu (2007) yang menunjukkan bahwa perilaku inovatif memberi kontribusi yang besar dalam meningkatkan produktivitas.Penelitian yang dilakukan oleh Kusumawati (2010) bahwa penerapan yang berhasil dari gagasan kreatif yang dimiliki perusahaan mampu menerapkan perilaku yang inovatif bagi karyawan yang dapat meningkatkan produktivitas dalam perusahaan.Putri dan Budiastuti (2012) menemukan bahwa perilaku inovatif memiliki pengaruh positif terhadap produktivitas, yang artinya bahwa dengan adanya perilaku inovatif 
INOBIS: Jurnal Inovasi Bisnis dan Manajemen Indonesia

Volume 2, Nomor 1, Desember 2018

A.A. Sagung Diah Istri Pramayani; I Gusti Ayu Dewi Adnyani

yang ditingkatkan dengan mendorong kreatifitas karyawan dapat meningkatkan kinerja karyawan.

\subsubsection{Pengaruh Motivasi Kerja Terhadap Produktivitas Kerja}

Motivasi kerja memperoleh rata-rata skor sebesar 4,00. Hal ini menunjukkan bahwa responden di Bumbu Bali Restoran memperoleh motivasi kerja yang tergolong dalam kategori baik.Hasil penelitian ini mendukung hipotesis ketiga $(\mathrm{H} 3)$ yaitu motivasi kerja berpengaruh positif terhadap produktivitas kerja karyawan di Bumbu Bali Restoran. Ismajili et al. (2015) menemukan bahwa motivasi memiliki pengaruh yang positif dan signifikan yang didukung dengan perolehan gaji, hasil kerja, kemajuan professional, dan kesempatan untuk promosi merupakan factor motivasi yang paling penting. Penelitian yang dilakukan Omollo (2015) menegaskan bahwa motivasi berpengaruh positif terhadap produktivitas karyawan jika imbalan yang diterima sesuai dengan apa yang menjadi beban pekerjaan karyawan itu. Chukwuma dan Okafor (2014) menemukan bahwa produktivitas karyawan yang tinggi dipengaruhi melalui motivasi kerja yang tinggi dengan sejumlah imbalan seperti intensif dan mengupayakan karyawan untuk melakukan upaya terbaik melalui antusiasme dan efektivitas untuk mencapai dan tujuan organisasi.

Hasil penelitian ini juga mendukung teori yang dikemukakan oleh Vroom (1964) tentang cognitive theory of motivation yang menentukan tinggi rendahnya motivasi seseorang ditentukan oleh tiga komponen yaitu:

1) Ekspektasi (harapan) keberhasilan pada suatu tugas

2) Instrumentalis, yaitu penilaian tentang apa yang akan terjadi jika berhasil dalam melakukan suatu tugas (keberhasilan tugas untuk mendapatkan outcome tertentu)

3) Valensi, yaitu respons terhadap outcome seperti perasaan positif, netral, atau negative. Motivasi tinggi jika usaha menghasilkan sesuatu yang melebihi harapan motivasi rendah jika usahanya menghasilkan kurang dari yang diharapkan.

\section{Simpulan dan Saran}

Berdasarkan hasil dan pembahasan yang telah diuraikan pada bab sebelumnya, maka diperoleh simpulan :

1. pemberdayaan memiliki pengaruh positif terhadap produktivitas kerja.

2. Perilaku inovatif memiliki pengaruh positif terhadap produktivitas kerja.

3. Motivasi kerja memiliki pengaruh positif terhadap produktivitas karyawan.

Berdasarkan hasil pembahasan yang telah diuraikan, maka dapat disarankan hal hal sebagai berikut :

Saran-saran yang dapat diberikan berdasarkan hasil pembahasan dalam penelitian yaitu perusahaan harus meningkatkan pemberdayaan dalam hal kredibilitas terhadap karyawan seperti melibatkan karyawan dalam proses perencanaan dan pembuatan keputusan. Dengan demikian, karyawan merasa lebih dipercayai dalam membuat suatu keputusan agar sesuai dengan tugas yang sudah diberikan. Dalam perilaku inovatif, Bumbu Bali Restoran harus meningkatkan bagaimana karyawan mengaplikasikan cara-cara baru dalam proses pelayanan. Cara yang lebih efektif dan mudah diaplikasikan oleh karyawan, sehingga terciptanya 
INOBIS: Jurnal Inovasi Bisnis dan Manajemen Indonesia

Volume 2, Nomor 1, Desember 2018

A.A. Sagung Diah Istri Pramayani; I Gusti Ayu Dewi Adnyani

kualitas pelayanan yang baik dan akan menumbuhkan citra positif bagi pelanggan Bumbu Bali Restoran.Bumbu Bali Restoran sebaiknya meninjau kembali fasilitas dan kelengkapan bekerja karyawan seperti perlengkapan dapur dan kebutuhan pekerjaan yang lain yang dirasa kurang memadai agar karyawan mampu melaksanakan tugas-tugasnya dengan baik dan nyaman.

\section{Daftar Pustaka}

Almigo, Nuzep. 2004. Hubungan Antara Kepuasan Kerja Dengan Produktivitas Kerja Karyawan. Jurnal PSYCHE, 1(1), h: 50-60.

Arifin, Alvin. 2014. Pengaruh Pemberdayaan dan Motivasi Terhadap Kinerja Karyawan (Studi Pada Karyawan CV. Catur Perkasa Manunggal). Jurusan

Administrasi Bisnis Fakultas Ilmu Administrasi Universitas Brawijaya. Jurnal Administrasi Bisnis (JAB), 8(2), h: 125-132.

Chang, Li-Ch , Chieh - Hsing Liu. 2007. Employee Empowerment, Innovative Behavior and Job Productivity of Public Healt Nurses: A Cross-sectional questionnaire survey. International Journal of Nursing Studies, 45(10), pp: 1442-1448.

Chehrazi, Karim Amir and Shafizadeh, Reza. 2016. The Relationship of Empowerment and Job Satisfaction with Productivity of Employees of Education System in Ahwaz. International Journal of Learning \& Development, 6 (1), pp: 11-24.

Chukwuma, Edwin Maduka \& Okafor, Dr. Obiefuna. 2014. Effect of Motivation on Employee Productivity: A Study of Manufacturing Companies in Nnewi. International Journal of Managerial and Research, 2(7), pp: 137-147.

Elnaga, A., \& Imran, A. (2013).The effect of training on employee performance.European Journal of Business and Management, 5(4), pp: 137-147.

Farr, J. L., and C. M. Ford. 1990 Individual Innovation, In M. A. West \& J. L. Farr (Eds.), Innovation and Creativity at Work: Psychological and Organizational Strategies, Chichester, UK: John Wiley \& Sons, pp: 63-80.

Ferreira, A, \& Du Plessis, T. 2009.Effect of Online social networking on employee productivity.South African Journal of Information Management, 11 (1), pp:1-11.

Hamali, Arif Yusuf. 2013. Pengaruh Motivasi Terhadap Produktivitas Kerja: Studi Kasus Pada PT X Bandung. Journal The WINNERS, 14(2), h: 77-86

Hanaysha, Jalal. 2016. Testing the Effects of Employee Empowerment, Teamwork, and Employee Productivity in Higher Education Sector. International Journal of Learning and Development, 6(1), p: 2164-4063.

Huzain, Sadam. 2015. Peran Pimpinan Dalam Meningkatkan Produktivitas Kerja Karyawan Pada PT. Graha Mandala Sakti Bontang.E-Journal Ilmu Pemerintahan, 3(1) h: 479493.

Ismajli Naim, Zekiri Jusuf, Qosja Ermira, Krasniqi. 2015. The Importance Of Motivation Factors on Employee Performance in Kosovo Municipalities.Journal of Public Administration and Governance. 5(1) pp: 23-39.

Jacquiline, F. N. (2014). Employee empowerment and job satisfaction.Researchjournali's Journal of Human Resource, 2(2), pp: 1-12.

Janssen, O. 2000. Job Demands, Perceptions of Effort-Reward Fairness and Innovative Work Behavior. Journal of Occupational and Organizational Psychology, 73(3), pp: 287302.

Karakoc, Nihat. 2009. Employee Empowerment and Differentiation in Companies: A Literature Review and Research Agenda. Enterprise Risk Management, 1 (2) pp: 1-12. 
INOBIS: Jurnal Inovasi Bisnis dan Manajemen Indonesia

Volume 2, Nomor 1, Desember 2018

A.A. Sagung Diah Istri Pramayani; I Gusti Ayu Dewi Adnyani

Kawara, P. 2014. Effect of reward system on Employee Productivity in catholic university of eastern Frica.International Journal of Recent Research in Commerce Economics and Management, 1 (2), pp: 1-4.

Khan, S. 2007. The Key Being a leader company empowerment. International Journal for Quality and Participation, 2(3), pp: 15-17

Kien , B.T. 2012. . Factors affecting the fluctuations of labour productivity in the construction projects. Master Thesis , University of Economics . Ho Chi Minh City, Vietnam.

Kresnandito, Putra A. \& Fajrianthi.(2012). Pengaruh Persepsi Kepemimpinan Transformasional terhadap Perilaku Inovatif Penyiar Radio. Jurnal Psikologi Industri dan Organisasi, 1 (02), h: 78-85.

Kusumawati, Ratna. 2010. Pengaruh Karakteristik Pimpinan dan Inovasi Produk Baru Terhadap Kinerja Perusahaan Untuk Mencapai Keunggulan Bersaing Berkelanjutan. Fakultas Ekonomi Universitas Wahid Hasyim. Jurnal Ekonomi Bisnis, 5(9), h: 53-64.

Martoyo Susilo, 2000, Manajemen Sumber Daya Manusia, Yogyakarta, BPFE.

Meyerson, G., and Dewettinck, B. 2012. Effect of empowerment on employees performance. Advanced Research in Economic and Management Sciences, 2(5), pp:40-46.

Noe, Ramond A., John R. Hollenbeck, Barry Gerhant, and Patrick M Wright. 2010. Human Resource Management, Gaining Competitive Advantage $3^{\text {rd }}$ Edition.McGraw-Hill.

Nurfitri, Titi dan Sri Lestari, 2009. Pengaruh Kepemimpinan Dan Motivasi Terhadap Kinerja Karyawan (Studi Komparasi RSUD Banyumas, Rs. Sinar Kasih, PT. PLN dan PDAM Kabupaten Banyumas. Perfomance, 10(1), h: 38-55.

Omollo, Pamela Akinyi. 2015. Effect Of Motivation On Employee Performance Of Commercial Banks In Kenya: A Case Study Of Kenya Comercial Bank In Migori County.Jomo Kenyata University of Agriculture and Technology Kenya.International Journal of Human Resource Studies. 5(2) pp: 87-103.

Purnama, Ridwan. 2008. Pengaruh Motivasi Kerja Terhadap Produktivitas Kerja Karyawan Pada Bagian Produksi CV. Epsilon Bandung.Jurnal Strategic, Volume 7, Nomor 14, September 2008.

Purba, S. 2009. Pengaruh Budaya Organisasi, Modal Intelektual, dan Perilaku Kerja Inovatif terhadap Kinerja Pemimpin Jurusan di Universitas Negeri Medan.Jurnal Bisnis dan Ekonomi. 13(2), h: 150-167.

Putri, Mita Andini \& Budiastuti, Dyah Ir.,MM.2012. Analisis Pengaruh Kreativitas dan Perilaku Inovatif Terhadap Kinerja Karyawan.

Rahmawati, Desi. 2013. Pengaruh Motivasi Terhadap Produktivitas Kerja Karyawan PR Fajar Berlian Tulungagung.Jurnal Universitas Tulungagung Bonorowo Vol.1 No.1 Tahun 2013.

Santoso, Singgih. 2006. Menguasai Statistik di era informasi dengan SPSS 15. Edisi Kedua. Jakarta: Elekmedia Computindo

Sedarmayanti.2001. Sumber Daya Manusia dan Produktivitas Kerja. Mandar Maju, Bandung.

Simanjuntak, Frishka Dora, dan Ahmad Calam. 2012. Pengaruh Kepemimpinan Transformasional dan Motivasi Kerja terhadap Kinerja Karyawan PT. PLN (Persero) Cabang Binjai Wilayah Sumatera Utara. Jurnal Saintikom, 11(2), h: 79-86.

Stewart, Aileen Mitchell. 2008. Pemberdayaan SDM. Edisi Terjemahan

Yogyakarta: Kanisius.

Sugiyono. 2012. Metode Penelitian Bisnis. Edisi Ketiga.

Sutrisno, dEdy. 2009. Manajemen Sumber Daya Manusia. Edisi Pertama. 
INOBIS: Jurnal Inovasi Bisnis dan Manajemen Indonesia

Volume 2, Nomor 1, Desember 2018

A.A. Sagung Diah Istri Pramayani; I Gusti Ayu Dewi Adnyani

Jakarta: Kencana

Tahira Nazir, Saif-Ur-Rehman Khan, Syed Fida Hussain Shah and Khalid Zaman. 2013. Impact of Rewards and Compensation on Job Statisfaction: Public and Private Universitas of UK.Midle-East Journal of Scientific Research 14(03): h:394-403

Utama, Made Suyasa.2012.Aplikasi Analisis Kuantitatif. Edisi Keenam. Denpasar: Fakultas Ekonomi Universitas Udayana.

Umar, Husein. 2007, Metode Penelitian Untuk Skripsi dan Tesis Bisnis. Jakarta: PT. Raja Grafindo Persada.

Wirawan, Nata. 2014. Cara Mudah Memahami Statistik 2 Statistik Inferensial

untuk Ekonomi dan Bisnis. Edisi Kedua. Denpasar : Keraras Emas.

Widodo, Suparno Eko. 2015. Manajemen Pengembangan Sumber Daya Manusia. Yogyakarta. Pustaka Pelajar

Wicaksono, Agil Danang. 2011. Peningkatan Produktivitas Kerja Karyawan Melalui Kepemimpinan, Disiplin Kerja, Motivasi, dan Kompensasi Pada PT. Danatrans Service Semarang. Fakultas Ekonomi dan Bisnis.

Yuan, F-R., and Woodman, R. W. 2010. Innovative Behavior in The Workplace: The Role of Performance and Image Outcome Expectations. Academy of Management Journal. 53(2), pp: 323-342. 